\title{
Survey of Respiratory Therapy Education Program Directors in the United States
}

\author{
Thomas A Barnes EdD RRT FAARC, Robert M Kacmarek PhD RRT FAARC, \\ and Charles G Durbin Jr MD FAARC
}

\begin{abstract}
OBJECTIVE: As background for the American Association for Respiratory Care (AARC) third 2015 and Beyond conference, we sought information and opinions on the ability of the current respiratory therapy education infrastructure to make changes that would assure competent respiratory therapists in the envisioned healthcare future. METHODS: After pilot testing and refining the questions, we invited the directors of 435 respiratory therapy programs (based in 411 colleges) that were fully accredited or in the process of being accredited by the Commission on Accreditation for Respiratory Care as of May, 2010, to participate in the survey. RESULTS: Three-hundred forty-eight program directors $(\mathbf{8 0} \%)$ provided valid survey responses. Three of the 5 competencies related to evidence-based medicine and respiratory care protocols were taught less often in the associate-degree programs than in the baccalaureate-degree programs. Eighty percent of the baccalaureate-degree programs, compared to $42 \%$ of the associate-degree programs, instruct students how to critique published research $(P<.001)$. Only $34 \%$ of the associate-degree programs teach students the general meaning of statistical tests, compared to $78 \%$ of the baccalaureate-degree programs $(P<.001)$. Ninety-four percent of the baccalaureate-degree programs, versus $81 \%$ of the associate-degree programs, teach the students to apply evidence-based medicine to clinical practice $(P=.01)$. Teaching students how to describe healthcare and financial reimbursement systems and the need to reduce the cost of delivering respiratory care (a leadership competency identified by the second 2015 and Beyond conference) was significantly more common in the baccalaureate-degree programs $(72 \%)$ than in the associate-degree programs $(56 \%)(P=.03)$. Other competencies showed trends toward differences, and the baccalaureate-degree programs reported higher percentages of success than the associate-degree programs. CONCLUSIONS: There are important differences between the baccalaureate-degree and associate-degree programs. Key words: respiratory care; respiratory therapist; survey; education; credentials; accreditation. [Respir Care 2011;56(12): 1906-1915. (C) 2011 Daedalus Enterprises]
\end{abstract}

\section{Introduction}

The first American Association for Respiratory Care (AARC) 2015 and Beyond conference defined the expected

\footnotetext{
Dr Barnes is affiliated with the Department of Health Sciences, Northeastern University, Boston, Massachusetts. Dr Kacmarek is affiliated with the Department of Anesthesiology, Massachusetts General Hospital, and with Harvard Medical School, Boston, Massachusetts. Dr Durbin is affiliated with the Department of Anesthesiology, University of Virginia, Charlottesville, Virginia.
}

Dr Barnes has disclosed a relationship with Mercury Medical. Dr Kacmarek has disclosed relationships with Space Labs, Puritan Bennett, Maquet, Cardinal Health, Newport Medical, Hamilton Medical, Respi- role of the practicing and graduating respiratory therapist in 2015 and beyond. ${ }^{1}$ The second 2015 and Beyond conference identified 67 competencies (in 8 categories) that

\footnotetext{
ronics, General Electric, and Dräger. Dr Durbin has disclosed relationships with Kimberly Clark and Masimo.

Supplementary material related to this paper is available at http:// www.rcjournal.com.

Correspondence: Thomas A Barnes EdD RRT FAARC, Department of Health Sciences, 316 Robinson Hall, Northeastern University, 360 Huntington Avenue, Boston MA 02115-5000. E-mail: t.barnes@neu.edu.
}

DOI: $10.4187 /$ respcare.01259 
will be required of respiratory therapists in 2015 and beyond. ${ }^{2}$ The goal of the third 2015 and Beyond conference was to determine the education, credentialing, and accreditation needs that would support the profession in attaining the competencies identified in the second conference. ${ }^{3}$ To ensure that the participants of the third conference would have as much information as possible on which to base their recommendations, the 2015 and Beyond conferences planning committee surveyed the directors of respiratory therapy (RT) education programs about their current and future ability to ensure that their graduating students will have the identified competencies. We also asked the program directors for their opinions on the required length of respiratory care programs in 2015 and beyond, the education needs of practicing therapists, and the credentials that will be needed by graduating therapists.

\section{See the Related Editorial on Page 1977}

The committee hypothesized that the RT education programs would not be able to ensure that their graduates could attain all the competencies identified in the second conference, that there would be differences in opinion between the associate-degree and baccalaureate-degree program directors on the education requirements of graduates, and that a large majority of education programs would consider the Registered Respiratory Therapist (RRT) credential necessary for entry into the profession in 2015 and beyond.

\section{Methods}

This study was conducted by the AARC's 2015 Research Group (see the supplementary materials at http:// www.rcjournal.com).

\section{Questionnaire Development and Pilot Testing}

Survey questions related to RT practice in 2015 and beyond were developed based on outcomes from the first and second 2015 and Beyond conferences and on information needed for the third conference. These questions were organized, reviewed, and discussed by group members, who have considerable academic and clinical experience in respiratory therapy practice, education, accreditation, certification, and licensure. The survey asked:

- General demographic questions about the respondent's institution (eg, degrees offered, institutional control, programs offered, and expected number of graduates in 2010 and future years)
- Which of the 67 competencies identified by the second 2015 and Beyond conference are taught in the RT program's curriculum?

- Can additional credit hours be added to the RT curriculum to teach the competencies needed in 2015 and beyond, and not exceed maximum degree requirements?

- Which degree and which RT credential should be required to enter practice, and to continue practice as a respiratory therapist in 2105 and beyond?

We pilot-tested the survey with 6 program directors of accredited associate-degree and baccalaureate-degree RT programs, and asked them to comment on:

- Time: How many minutes were required to complete the survey?

- Clarity: Were any questions ambiguous?

- Invitation: Was the survey invitation letter easily understood and appropriate?

- Connection: Did the link provided connect you to the online survey easily? Were you able to submit the survey easily?

- Progression: Were you able to easily move forward and backwards between survey questions?

- Overall: What general comments do you have regarding the survey?

The survey was revised according to the pilot-test feedback, and approved by the 2015 Research Group (see the supplementary materials at http://www.rcjournal.com). The study protocol was approved by the institutional review board of Northeastern University.

\section{Data Collection}

The survey population was the directors of 435 RT programs based in 411 colleges accredited or in the process of being accredited by the Commission on Accreditation for Respiratory Care as of May 2010. The AARC President sent an invitation, via e-mail, to the 435 program directors, asking that they complete the survey. The directors' e-mail addresses were obtained from the Committee on Accreditation for Respiratory Care, and the Internet-based survey was self-administered. We sent 3 e-mail follow-up reminders to non-respondents.

\section{Data Analysis}

Data were aggregated according to response categories for type of RT program (associate or baccalaureate degree). With statistics software (SPSS 18.0, SPSS, Chicago, Illinois) we calculated percentages, frequency distribution, 


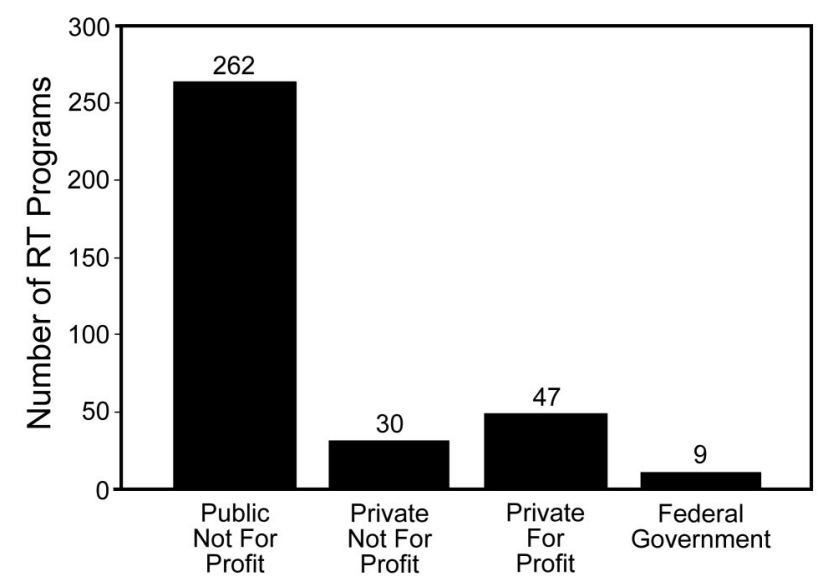

Fig. 1. Institutional control of 348 respiratory therapy education programs, according to the program directors.

and differences between program types with cross tabulation and Pearson chi-square analysis. A two-tailed $P<.05$ was considered statistically significant.

\section{Results}

\section{Response Rate and Demographics}

We received 348 valid responses (response rate 80\%). Six colleges had more than one program director because of students located on satellite campuses, and those 6 colleges collectively submitted 30 survey responses. At least one program-director response was received from $324 \mathrm{col}-$ leges $(79 \%)$ of the 411 colleges with RT programs. Institutional control was reported as public not-for-profit by $271(78 \%)$, and as private by 77 (22\%) (Fig. 1). Community and junior colleges were the most common institution type (Fig. 2). The associate degree is offered by 294 of the programs. The baccalaureate degree is offered by 54 of the programs (Fig. 3).

\section{Major Competency Areas}

There were statistically significant differences between the competencies taught by the baccalaureate-degree programs and the associate-degree programs in evidence-based medicine and protocols (Table 1), leadership (Table 2), and diagnostics (Table 3 ). There were differences $>6 \%$ in the chronic and acute disease-management competencies (Table 4), the emergency competencies (Table 5), and the critical care competencies (Table 6). The differences were $<5 \%$ in the patient-assessment competencies (Table 7), the therapeutics competencies (Table 8), and the therapeutic applications competencies (Table 9).

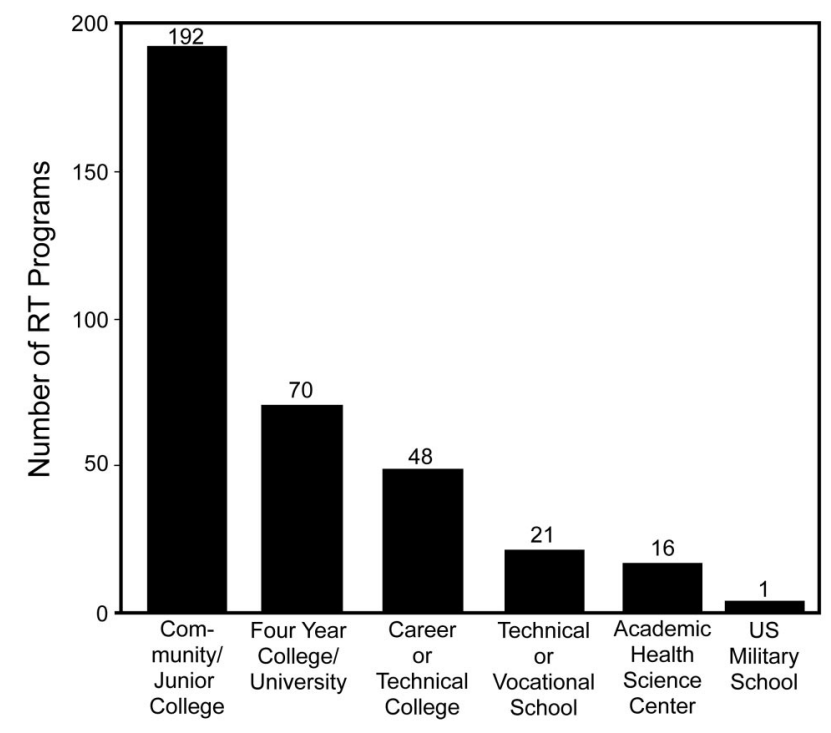

Fig. 2. Types of institutions of 348 respiratory therapy education programs, according to the program directors.

\section{Evidence-Based Medicine and Respiratory Care Protocols}

Three of the 5 competencies related to evidence-based medicine and respiratory care protocols were taught significantly more often by the baccalaureate-degree programs than the associate-degree programs (see Table 1). Eighty percent of the baccalaureate-degree programs, compared to $42 \%$ of the associate-degree programs, instruct students in how to critique published research $(P<.001)$. Seventyeight percent of the baccalaureate-degree programs teach students the general meaning of statistical tests, compared to $34 \%$ of the associate-degree programs $(P<.001)$. The respondents reported that students are taught to apply evidence-based medicine to clinical practice in $94 \%$ of the baccalaureate-degree programs and $81 \%$ of the associatedegree programs $(P=.01)$. Both types of programs teach students how to treat patients in a variety of settings, using the appropriate respiratory care protocols (baccalaureatedegree programs 96\%, associate-degree programs 95\%) and explain to students the use of evidence-based medicine in the development of hospital-based respiratory care protocols (baccalaureate-degree programs $83 \%$, associatedegree $79 \%$ ).

\section{Leadership}

Teaching students to describe healthcare financial reimbursement and the need to reduce the cost of delivering respiratory care (a leadership competency identified by the second 2015 and Beyond conference) was significantly different between the baccalaureate-degree programs (72\%) 


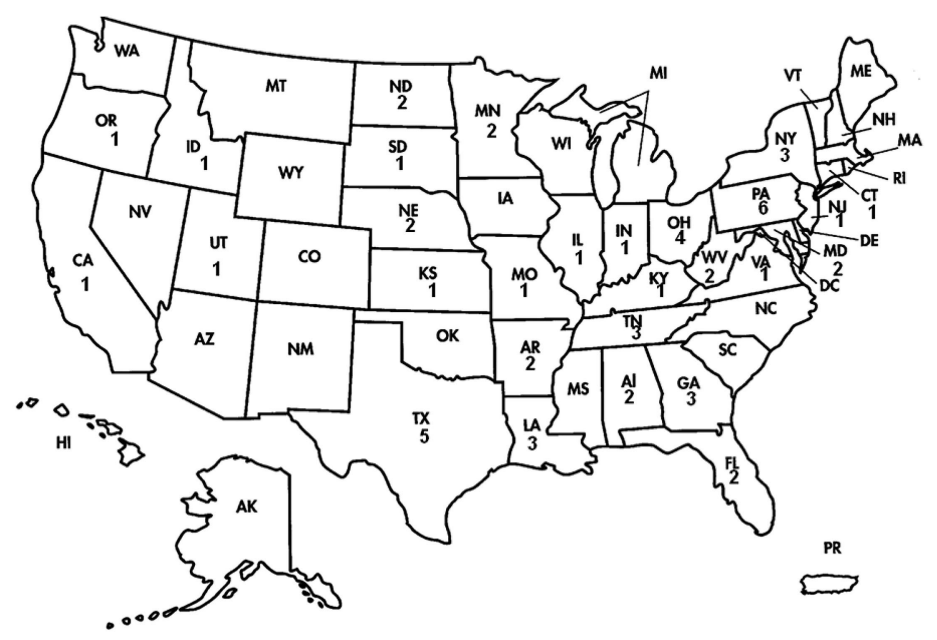

Fig. 3. Colleges and universities that award a baccalaureate of science degree in respiratory therapy. (Adapted from Reference 4, with permission.)

Table 1. Evidence-Based Medicine and Respiratory Care Protocol Competencies

\begin{tabular}{|c|c|c|c|}
\hline & \multicolumn{2}{|c|}{ Respondents $(\%)^{*}$} & \multirow[b]{2}{*}{$P$} \\
\hline & $\begin{array}{l}\text { Baccalaureate } \\
\text { Program }\end{array}$ & $\begin{array}{l}\text { Associate } \\
\text { Program }\end{array}$ & \\
\hline $\begin{array}{l}\text { Critique published research } \\
\quad(\text { no. }=165)\end{array}$ & 80 & 42 & $<.001$ \\
\hline $\begin{array}{l}\text { Explain the meaning of } \\
\text { general statistical tests } \\
\text { (no. }=142)\end{array}$ & 78 & 34 & $<.001$ \\
\hline $\begin{array}{l}\text { Apply evidence-based } \\
\text { medicine to clinical } \\
\text { practice }(\text { no. }=288)\end{array}$ & 94 & 81 & .01 \\
\hline $\begin{array}{l}\text { Explain the use of evidence- } \\
\text { based medicine in the } \\
\text { development and } \\
\text { application of hospital- } \\
\text { based respiratory care } \\
\text { protocols (no. }=276 \text { ) }\end{array}$ & 83 & 79 & .43 \\
\hline $\begin{array}{l}\text { Treat patients in a variety of } \\
\text { settings, using the } \\
\text { appropriate respiratory } \\
\text { care protocol }(\text { no. }=332 \text { ) }\end{array}$ & 96 & 95 & .73 \\
\hline
\end{tabular}

and associate-degree programs $(56 \%)(P=.03)$. Both the baccalaureate-degree programs $(63 \%)$ and associate-degree programs $(52 \%)$ are preparing students to lead groups in care planning, bedside decision making, and collaboration with other healthcare professionals $(P=.15)$. Teaching students to contribute to organizational teams as related to planning, collaborative decision making, and other team functions, was also reported by both the baccalaureatedegree programs $(78 \%)$ and associate-degree programs $(66 \%)(P=.09)$. Basic organizational implications of reg-
Table 2. Leadership Competencies

\begin{tabular}{|c|c|c|c|}
\hline & \multicolumn{2}{|c|}{ Respondents (\%)* } & \multirow[b]{2}{*}{$P$} \\
\hline & $\begin{array}{c}\text { Baccalaureate } \\
\text { Program }\end{array}$ & $\begin{array}{l}\text { Associate } \\
\text { Program }\end{array}$ & \\
\hline $\begin{array}{l}\text { Contribute to organizational } \\
\text { teams as related to } \\
\text { planning, collaborative } \\
\text { decision making, and other } \\
\text { team functions }(\text { no. }=236 \text { ) }\end{array}$ & 78 & 66 & $.09 \dagger$ \\
\hline $\begin{array}{l}\text { Describe fundamental/basic } \\
\text { organizational implications } \\
\text { of regulatory requirements } \\
\text { on the healthcare system } \\
\text { (no. }=235 \text { ) }\end{array}$ & 76 & 66 & $.15 \dagger$ \\
\hline $\begin{array}{l}\text { Demonstrate effective written } \\
\text { and verbal communications } \\
\text { with various members of } \\
\text { the healthcare team, } \\
\text { patients, families, and } \\
\text { others (cultural competence } \\
\text { and literacy) (no. }=327 \text { ) }\end{array}$ & 94 & 94 & .87 \\
\hline $\begin{array}{l}\text { Describe healthcare financial } \\
\text { reimbursement systems and } \\
\text { the need to reduce the cost } \\
\text { of delivering respiratory } \\
\text { care }(\text { no. }=204)\end{array}$ & 72 & 56 & .03 \\
\hline $\begin{array}{l}\text { Lead groups in care planning, } \\
\text { bedside decision making, } \\
\text { and collaboration with other } \\
\text { healthcare professionals } \\
\text { (no. }=188 \text { ) }\end{array}$ & 63 & 52 & $.15 \dagger$ \\
\hline
\end{tabular}

*n=348 (total programs responding): 294 associate programs; 54 baccalaureate programs. $\dagger$ Difference $>6 \%$.

ulatory requirements on the healthcare system were reportedly taught by both the baccalaureate-degree programs $(76 \%)$ and associate-degree programs $(66 \%)(P=.15)$. 


\section{Survey of Respiratory Therapy Education Program Directors in the United States}

Table 3. Diagnostic Competencies

\begin{tabular}{|c|c|c|c|}
\hline & \multicolumn{2}{|c|}{ Respondents $(\%)^{*}$} & \multirow[b]{2}{*}{$P$} \\
\hline & $\begin{array}{l}\text { Baccalaureate } \\
\text { Program }\end{array}$ & $\begin{array}{l}\text { Associate } \\
\text { Program }\end{array}$ & \\
\hline $\begin{array}{l}\text { Perform basic spirometry } \\
\quad(\text { no. }=343)\end{array}$ & 100 & 98 & .33 \\
\hline $\begin{array}{l}\text { Explain indications and } \\
\text { contraindications for } \\
\text { advanced pulmonary function } \\
\text { tests (no. }=325 \text { ) }\end{array}$ & 100 & 92 & .03 \\
\hline $\begin{array}{l}\text { Explain indications and } \\
\text { contraindications for sleep } \\
\text { studies }(\text { no. }=296)\end{array}$ & 93 & 84 & $.09 \dagger$ \\
\hline $\begin{array}{l}\text { Relate results of sleep studies to } \\
\text { types of sleep disorders } \\
(\text { no. }=239)\end{array}$ & 76 & 67 & $.21 \dagger$ \\
\hline $\begin{array}{l}\text { Explain indications and } \\
\text { contraindications, general } \\
\text { hazards, and complications of } \\
\text { bronchoscopy (no. }=329 \text { ) }\end{array}$ & 96 & 94 & .54 \\
\hline $\begin{array}{l}\text { Describe the bronchoscopy } \\
\text { procedure and the respiratory } \\
\text { therapist's role in assisting } \\
\text { the physician }(\text { no. }=330)\end{array}$ & 100 & 94 & $.06 \dagger$ \\
\hline $\begin{array}{l}\text { Evaluate monitoring of a } \\
\text { patient's clinical condition } \\
\text { with pulse oximetry, } \\
\text { electrocardiogram, exhaled- } \\
\text { gas analysis, and other } \\
\text { related devices }(\text { no. }=344 \text { ) }\end{array}$ & 100 & 99 & .39 \\
\hline $\begin{array}{l}\text { Perform arterial puncture and } \\
\text { sampling, and blood analysis } \\
(\text { no. }=343)\end{array}$ & 100 & 98 & .33 \\
\hline
\end{tabular}

Both types of programs had a high proportion that taught effective written and verbal communications with various members of the healthcare team, patients, families, and others (see Table 2).

\section{Other Competency Areas With Differences}

A high proportion of both the baccalaureate-degree programs $(>93 \%)$ and associate-degree programs $(>84 \%)$ teach most competencies in diagnostics, except for the competency of relating the results of sleep studies to sleep disorders (baccalaureate-degree programs 76\%, associatedegree programs $67 \%$, see Table 3). Overall, the baccalaureate-degree programs reported teaching competencies in diagnostics more often than did the associate-degree programs.

Eighty-nine percent of the baccalaureate-degree programs teach all the competencies in chronic and acute disease management, except for to develop, administer,
Table 4. Chronic and Acute Disease-Management Competencies

\begin{tabular}{|c|c|c|c|}
\hline & \multicolumn{2}{|c|}{ Respondents $(\%)^{*}$} & \multirow[b]{2}{*}{$P$} \\
\hline & $\begin{array}{c}\text { Baccalaureate } \\
\text { Program }\end{array}$ & $\begin{array}{l}\text { Associate } \\
\text { Program }\end{array}$ & \\
\hline $\begin{array}{l}\text { Explain the etiology, anatomy, } \\
\text { pathophysiology, diagnosis, } \\
\text { and treatment of } \\
\text { cardiopulmonary diseases } \\
\text { (eg, asthma, COPD) and } \\
\text { comorbidities (no. }=345 \text { ) }\end{array}$ & 100 & 99 & .46 \\
\hline $\begin{array}{l}\text { Engage patients through } \\
\text { communication, education, } \\
\text { and empowerment } \\
\text { (no. = 304) }\end{array}$ & 89 & 87 & .71 \\
\hline $\begin{array}{l}\text { Develop, administer, and } \\
\text { reevaluate the care plan for } \\
\text { chronic disease management } \\
\text { (no. }=275 \text { ) }\end{array}$ & 83 & 78 & .40 \\
\hline $\begin{array}{l}\text { Manage respiratory care plans } \\
\text { in the acute-care setting, } \\
\text { using evidence-based } \\
\text { medicine, protocols, and } \\
\text { clinical practice guidelines } \\
\text { (no. }=315 \text { ) }\end{array}$ & 96 & 90 & $.12 \dagger$ \\
\hline
\end{tabular}

and reevaluate the care plan for chronic disease management: only $83 \%$ teach that competency (see Table 4). A larger proportion of the baccalaureate-degree programs than the associate-degree programs teach the disease-management competencies, and the largest difference $(6 \%)$ was for the competencies to manage the respiratory care plan in the acute-care setting, and to use evidence-based medicine, protocols, and clinical practice guidelines.

Ninety-one percent of the baccalaureate-degree programs and the associate-degree programs teach their students patient-assessment competencies. Fewer baccalaureatedegree programs $(91 \%)$ than associate-degree programs (95\%) teach students how to obtain social, behavioral, occupational, and other historical information about the current complaint. All the baccalaureate-degree programs and $98 \%$ of the associate-degree programs teach students how to interpret pulmonary function studies (spirometry). More baccalaureate-degree programs than associate-degree programs teach students to interpret lung volumes and diffusion studies (see Table 7).

The emergency care competencies are taught by a higher proportion of the baccalaureate-degree programs than the associate-degree programs (see Table 5). Fewer programs of both types teach students how to provide emergency care to children and neonates. A relatively low proportion of the baccalaureate-degree programs and the associatedegree programs are training students how to perform as a 


\section{Survey of Respiratory Therapy Education Program Directors in the United States}

Table 5. Emergency Care Competencies

\begin{tabular}{|c|c|c|c|}
\hline & \multicolumn{2}{|c|}{ Respondents $(\%)^{*}$} & \multirow[b]{2}{*}{$P$} \\
\hline & $\begin{array}{l}\text { Baccalaureate } \\
\text { Program }\end{array}$ & $\begin{array}{l}\text { Associate } \\
\text { Program }\end{array}$ & \\
\hline $\begin{array}{l}\text { Perform basic life support } \\
\quad(\text { no. }=336)\end{array}$ & 100 & 96 & .13 \\
\hline $\begin{array}{l}\text { Perform advanced cardiovascular } \\
\text { life support }(\text { no. }=298)\end{array}$ & 89 & 85 & .46 \\
\hline $\begin{array}{l}\text { Perform pediatric advanced life } \\
\text { support (no. }=180 \text { ) }\end{array}$ & 56 & 51 & .54 \\
\hline $\begin{array}{l}\text { Perform neonatal resuscitation } \\
\text { program }(\text { no. }=211)\end{array}$ & 67 & 60 & $.32 \dagger$ \\
\hline $\begin{array}{l}\text { Perform endotracheal intubation } \\
\quad(\text { no. }=331)\end{array}$ & 98 & 95 & .26 \\
\hline $\begin{array}{l}\text { Maintain current American Heart } \\
\text { Association certification in } \\
\text { basic life support and advanced } \\
\text { cardiovascular life support } \\
\text { (no. }=275 \text { ) }\end{array}$ & 89 & 77 & $.053 \dagger$ \\
\hline $\begin{array}{l}\text { Perform as a member of the rapid } \\
\text { response team (medical } \\
\text { emergency team) }(\text { no. }=230)\end{array}$ & 72 & 65 & $.30 \dagger$ \\
\hline $\begin{array}{l}\text { Participate in mass-casualty } \\
\text { staffing to provide airway } \\
\text { management, manual and } \\
\text { mechanical ventilatory life } \\
\text { support, medical gas } \\
\text { administration, aerosol delivery } \\
\text { of bronchodilators and other } \\
\text { agents in the resuscitation of } \\
\text { respiratory and cardiovascular } \\
\text { failure (no. }=169 \text { ) }\end{array}$ & 54 & 48 & $.41 \dagger$ \\
\hline $\begin{array}{l}\text { Provide intra-hospital transport of } \\
\text { critically and chronically ill } \\
\text { patients, provide } \\
\text { cardiopulmonary life support } \\
\text { and airway control during } \\
\text { transport (no. }=282 \text { ) }\end{array}$ & 87 & 80 & $.22 \dagger$ \\
\hline $\begin{array}{l}\text { Recommend pharmacotherapy in } \\
\text { clinical settings, including } \\
\text { emergencies (no. }=321 \text { ) }\end{array}$ & 94 & 92 & .51 \\
\hline
\end{tabular}

member of a rapid response team: $72 \%$ and $65 \%$ respectively. Eighty-nine percent of the baccalaureate-degree programs and $77 \%$ of the associate-degree programs require students to maintain current American Heart Association advanced cardiovascular life support and basic life support certification. About half of both types of programs teach students how to participate in mass-casualty staffing (see Table 5).

The largest differences in the critical care competencies was in the number of programs that teach how to participate in collaborative care management based on evidencebased protocols: $82 \%$ and $71 \%$ in the baccalaureatedegree and associate-degree programs, respectively (see
Table 6. Critical Care Competencies

\begin{tabular}{|c|c|c|c|}
\hline & \multicolumn{2}{|c|}{ Respondents $(\%)^{*}$} & \multirow[b]{2}{*}{$P$} \\
\hline & $\begin{array}{l}\text { Baccalaureate } \\
\text { Program }\end{array}$ & $\begin{array}{l}\text { Associate } \\
\text { Program }\end{array}$ & \\
\hline $\begin{array}{l}\text { Apply invasive and noninvasive } \\
\text { mechanical ventilation } \\
(\text { no. }=341)\end{array}$ & 98 & 98 & .93 \\
\hline $\begin{array}{l}\text { Apply all ventilation modes } \\
\text { currently available on all } \\
\text { invasive and noninvasive } \\
\text { mechanical ventilators, as } \\
\text { well as adjunct to mechanical } \\
\text { ventilation (no. }=335 \text { ) }\end{array}$ & 100 & 96 & .12 \\
\hline $\begin{array}{l}\text { Interpret ventilator data and } \\
\text { hemodynamic monitoring } \\
\text { data and calibrate monitoring } \\
\text { devices }(\text { no. }=334)\end{array}$ & 100 & 95 & .10 \\
\hline $\begin{array}{l}\text { Manage airway devices and } \\
\text { sophisticated monitoring } \\
\text { systems }(\text { no. }=338)\end{array}$ & 100 & 97 & .17 \\
\hline $\begin{array}{l}\text { Make recommendations for } \\
\text { treatment based on wave- } \\
\text { form graphics, pulmonary } \\
\text { mechanics, and related } \\
\text { imaging studies (no. }=328 \text { ) }\end{array}$ & 96 & 94 & .48 \\
\hline $\begin{array}{l}\text { Use therapeutic medical gases } \\
\text { to treat critically ill patients } \\
\text { (no. }=333 \text { ) }\end{array}$ & 94 & 96 & .62 \\
\hline $\begin{array}{l}\text { Apply circulatory gas-exchange } \\
\text { systems in respiratory therapy } \\
\text { practice }(\mathrm{eg}, \text { ECMO) } \\
\text { (no. }=154)\end{array}$ & 44 & 44 & .98 \\
\hline $\begin{array}{l}\text { Participate in collaborative care } \\
\text { management based on } \\
\text { evidence-based protocols } \\
(\text { no. }=252 \text { ) }\end{array}$ & 82 & 71 & $.11 \dagger$ \\
\hline $\begin{array}{l}\text { Deliver therapeutic } \\
\text { interventions based on } \\
\text { protocol }(\text { no. }=326)\end{array}$ & 98 & 93 & .14 \\
\hline $\begin{array}{l}\text { Integrate the delivery of basic } \\
\text { and/or advanced therapeutics } \\
\text { in conjunction with or } \\
\text { without the mechanical } \\
\text { ventilator in the care of } \\
\text { critically ill patients } \\
\text { (no. }=331 \text { ) }\end{array}$ & 100 & 94 & .07 \\
\hline $\begin{array}{l}\text { Make recommendations, and } \\
\text { provide treatment to critically } \\
\text { ill patients based on } \\
\text { pathophysiology (no. }=331 \text { ) }\end{array}$ & 94 & 95 & .80 \\
\hline $\begin{array}{l}\text { Recommend cardiovascular } \\
\text { drugs based on knowledge } \\
\text { and understanding of } \\
\text { pharmacologic action } \\
\text { (no. }=302 \text { ) }\end{array}$ & 89 & 86 & .62 \\
\hline $\begin{array}{l}\text { Use electronic data systems in } \\
\text { respiratory therapy practice } \\
(\text { no. }=307)\end{array}$ & 94 & 87 & $.12 \dagger$ \\
\hline
\end{tabular}




\section{Survey of Respiratory Therapy Education Program Directors in the United States}

Table 7. Patient Assessment Competencies

\begin{tabular}{|c|c|c|c|}
\hline & \multicolumn{2}{|c|}{ Respondents $(\%)^{*}$} & \multirow[b]{2}{*}{$P$} \\
\hline & $\begin{array}{l}\text { Baccalaureate } \\
\text { Program }\end{array}$ & $\begin{array}{l}\text { Associate } \\
\text { Program }\end{array}$ & \\
\hline $\begin{array}{l}\text { Complete a patient assessment } \\
\text { through physical examination, } \\
\text { chart review, and other means, } \\
\text { as appropriate, and interact } \\
\text { with healthcare team members } \\
\text { about assessment results } \\
\text { (no. }=344)\end{array}$ & 98 & 99 & .60 \\
\hline $\begin{array}{l}\text { Obtain medical, surgical, and } \\
\text { family history (no. }=337 \text { ) }\end{array}$ & 96 & 97 & .80 \\
\hline $\begin{array}{l}\text { Obtain social, behavioral, } \\
\text { occupational, and other } \\
\text { historical information about the } \\
\text { current complaint } \\
\text { (no. = 329) }\end{array}$ & 91 & 95 & .18 \\
\hline $\begin{array}{l}\text { Interpret pulmonary function } \\
\text { studies (spirometry) } \\
\quad(\text { no. }=343)\end{array}$ & 100 & 98 & .33 \\
\hline $\begin{array}{l}\text { Interpret lung volumes and } \\
\text { diffusion studies }(\text { no. }=330)\end{array}$ & 98 & 94 & .23 \\
\hline $\begin{array}{l}\text { Interpret arterial blood gases, } \\
\text { electrolytes, complete blood } \\
\text { cell count, and related } \\
\text { laboratory tests (no. }=346 \text { ) }\end{array}$ & 100 & 99 & .54 \\
\hline $\begin{array}{l}\text { Inspect the chest and extremities } \\
\text { to detect deformation, cyanosis, } \\
\text { edema, clubbing, and other } \\
\text { anomalies }(\text { no. }=344)\end{array}$ & 100 & 99 & .39 \\
\hline $\begin{array}{l}\text { Measure vital signs }(\text { blood } \\
\text { pressure, heart rate, and } \\
\text { respiratory rate) }(\text { no. }=346)\end{array}$ & 100 & 99 & .54 \\
\hline $\begin{array}{l}\text { Evaluate patient breathing effort, } \\
\text { ventilatory pattern, and use of } \\
\text { accessory muscles }(\text { no. }=345 \text { ) }\end{array}$ & 100 & 99 & .46 \\
\hline $\begin{array}{l}\text { Document } \mathrm{S}_{\mathrm{pO}_{2}} \text { measurements } \\
\text { under all appropriate conditions } \\
\text { (with or without oxygen, at } \\
\text { rest, during sleep, ambulation, } \\
\text { and exercise) (no. }=339 \text { ) }\end{array}$ & 98 & 97 & .71 \\
\hline
\end{tabular}

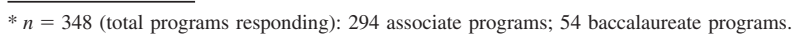

Table 6). Less than half of either program type teaches students to apply circulatory gas-exchange systems (eg, extracorporeal membrane oxygenation) in practice (see Table 6).

\section{Projected Numbers of Graduates and Factors That Impact Enrollment}

The respondents expected the average number of graduates per program to increase $25 \%$ over the next decade, from 20 in 2010 to 25 in 2020 (Table 10). Using the median data, the number of graduates would increase by
Table 8. Therapeutics Competencies

\begin{tabular}{lccc}
\hline \hline & \multicolumn{2}{c}{ Respondents $(\%) *$} & \\
\cline { 2 - 3 } & $\begin{array}{c}\text { Baccalaureate } \\
\text { Program }\end{array}$ & $\begin{array}{c}\text { Associate } \\
\text { Program }\end{array}$ & $P$ \\
\hline Assess therapy (no. $=340)$ & 100 & 97 & .22 \\
Assess a patient prior to therapy & 98 & 98 & .81 \\
$\quad($ no. $=$ 340) & & & \\
Administer therapy (no. $=342)$ & 100 & 98 & .29 \\
Evaluate therapy (no. $=338)$ & 98 & 97 & .62
\end{tabular}

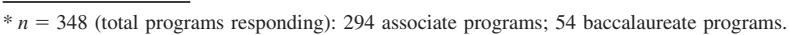

Table 9. Therapeutic Applications Competencies

\begin{tabular}{lccc}
\hline \hline & \multicolumn{2}{c}{ Respondents $(\%)^{*}$} & \\
\cline { 2 - 3 } & $\begin{array}{c}\text { Baccalaureate } \\
\text { Program }\end{array}$ & $\begin{array}{c}\text { Associate } \\
\text { Program }\end{array}$ & $P$ \\
\hline Medical gas therapy (no. $=340)$ & 100 & 97 & .22 \\
Humidity therapy (no. $=341)$ & 100 & 98 & .25 \\
Aerosol therapy (no. $=341)$ & 100 & 98 & .25 \\
Hyperinflation therapy $($ no. $=340)$ & 100 & 97 & .22 \\
Bronchial hygiene therapy $($ no. $=341)$ & 100 & 98 & .25 \\
Airway management $($ no. $=339)$ & 100 & 97 & .19 \\
Mechanical ventilation $($ no. $=337)$ & 94 & 97 & .27
\end{tabular}

$* n=348$ (total programs responding): 294 associate programs; 54 baccalaureate programs.

Table 10. Projected Graduates in Surveyed Respiratory Therapy Programs

\begin{tabular}{cccccc}
\hline \hline Year & $\begin{array}{c}\text { Respondents, } \\
\text { no. }\end{array}$ & \multicolumn{4}{c}{ Projected Graduates } \\
\cline { 3 - 6 } & Mean \pm SD & Median & Minimum & Maximum \\
\hline 2010 & 341 & $20 \pm 18$ & 15 & 0 & 120 \\
2012 & 338 & $23 \pm 17$ & 18 & 0 & 120 \\
2015 & 324 & $25 \pm 17$ & 20 & 5 & 130 \\
2020 & 321 & $25 \pm 16$ & 20 & 5 & 100 \\
\hline
\end{tabular}

one third, from 15 to 20 per program. Three-hundred forty-one programs answered the question on the number of graduates in 2010. The largest barriers to accepting more students into RT programs were inadequate number of clinical affiliates, limited availability of additional faculty, and lack of funding to expand (Table 11). Half of the program directors reported difficulty recruiting faculty, and $67 \%$ of that group indicated that lack of teaching experience, inadequate salary, and lack of academic credentials contributed to the recruitment problem. Twenty-six percent of the programs can allow program graduates to directly earn a baccalaureate degree. More of the baccalaureate-degree programs $(85 \%)$ than the associate-degree programs (15\%) directly award the baccalaureate degree to graduates. The baccalaureate-degree programs that 
Table 11. Barriers to Accepting More Students in Surveyed Respiratory Therapy Programs

\begin{tabular}{|c|c|c|c|c|c|c|}
\hline & \multicolumn{5}{|c|}{ Relevance, no. (\%) } & \multirow[b]{2}{*}{ Total } \\
\hline & $\begin{array}{c}1 \\
\text { (lowest) }\end{array}$ & 2 & 3 & 4 & $\begin{array}{c}5 \\
\text { (highest) }\end{array}$ & \\
\hline Inadequate number of clinical affiliates & $58(17)$ & $27(8)$ & $38(11)$ & $63(18)$ & $160(46)$ & 346 \\
\hline Additional faculty unavailable & $70(20)$ & $51(15)$ & $62(18)$ & $83(24)$ & $82(24)$ & 348 \\
\hline Competition from other respiratory therapy programs & $88(25)$ & $60(17)$ & $80(23)$ & $71(20)$ & $49(14)$ & 348 \\
\hline Competition from other healthcare programs & $93(27)$ & $59(17)$ & $83(24)$ & $66(19)$ & $45(13)$ & 346 \\
\hline Funding to expand program unavailable & $60(17)$ & $48(14)$ & $74(21)$ & $83(24)$ & $83(24)$ & 348 \\
\hline Insufficient classroom/lab space & $83(24)$ & $56(16)$ & $67(19)$ & $74(21)$ & $65(19)$ & 345 \\
\hline
\end{tabular}

indirectly award a baccalaureate degree in RT do so through consortia agreements with colleges and universities (eg, academic health science centers with accredited RT programs).

\section{Education Level and Credentials to Enter Practice}

One-hundred two respondents indicated that a baccalaureate or master's degree in respiratory therapy should be required to qualify for a license to deliver respiratory care in 2015 and beyond. However, 241 thought the associate degree was all that should be needed to begin practice as a respiratory therapist. Eighty-seven percent of the baccalaureate-degree program directors thought that a baccalaureate or master's degree should be required for entry. Eighty-one percent of the associate-degree program directors thought that an associate degree should be required for entry. There was more agreement on the education level after licensure: all of the baccalaureate-degree program directors and $66 \%$ of the associate-degree program directors favored requiring a baccalaureate or master's degree to progress in practice.

Sixty-nine percent of all respondents were in favor of the RRT credential being required to practice in 2015 and beyond: $83 \%$ among the baccalaureate-degree program directors, and $66 \%$ among the associate-degree program directors. Three-hundred $(86 \%)$ of all respondents indicated that future RT graduates should be required to maintain an active Certified Respiratory Therapist (CRT) or RRT credential to renew their state license to practice respiratory care. Only 48 (14\%) of all respondents were opposed to that requirement.

\section{Accelerated and Associate to Baccalaureate Bridge Programs}

Forty-four $(80 \%)$ of the baccalaureate-degree program directors reported that they offer an associate-degree to baccalaureate-degree program option. Fifteen (27\%) of the baccalaureate-degree programs offer an accelerated baccalaureate program for individuals who have already com- pleted a baccalaureate or graduate degree in a non-respiratory discipline. Twelve (22\%) of the baccalaureate-degree programs plan to start new accelerated programs by 2015. One-hundred thirty-two (38\%) of all respondents reported that their college has an articulation agreement with another institution to award a baccalaureate degree. Twentyone programs plan to offer a baccalaureate or master's degree in respiratory therapy in the future: 19 of them by 2015. Two-hundred eleven programs reported that the largest barrier to offering a baccalaureate degree was that their college does not award baccalaureate degrees.

Sixty percent of all respondents had the ability to increase the number of credit hours in their curriculums to teach new competencies, and 92\% said they could accomplish that by 2015. The directors who are unable to add credit hours to their curriculums indicated that they plan to teach the competencies needed in 2015 by revising their curriculums. ${ }^{2}$

\section{Discussion}

The major findings of this national survey are:

- Six of the 8 major competency areas identified by the second 2015 and Beyond conference have several competencies that are taught in more of the baccalaureatedegree programs than in the associate-degree programs.

- One quarter of the respondents have the capability to directly award a baccalaureate degree.

- Two thirds of the respondents favor requiring the RRT credential to practice in 2015 and beyond.

- There was broad support for future respiratory therapists obtaining a baccalaureate or graduate degree after they have begun practice.

- One-hundred respondents favored requiring a baccalaureate or graduate degree to qualify for a license to deliver respiratory care.

Strong evidence supports that in 2015 and beyond, respiratory therapists will need to master 67 competencies in 
8 major $\operatorname{areas}^{2}$ and understand the scientific evidence, because healthcare is increasingly driven by evidence-based medicine. ${ }^{1,5}$ Disease management is one of the major competency areas that will be needed in 2015 and beyond, ${ }^{1}$ and respiratory therapists will have to increase their scope of knowledge and skills to assimilate into the new diseasemanagement model. They will need to expand and refine their critical thinking and communication skills, receive training in finance, and increase their ability to analyze the literature. ${ }^{6}$

Leadership was one of 8 major competency areas identified by the second 2015 and Beyond conference. ${ }^{2}$ The present survey found that substantially fewer associatedegree than baccalaureate-degree programs teach students how to describe healthcare financial reimbursement systems. The respondent program directors reported that leadership skills for serving as a member or leader of interdisciplinary clinical teams are taught more often by the baccalaureate-degree programs. This presents a serious challenge for the next decade, because currently only one quarter of the respondent accredited RT programs can offer a baccalaureate or graduate degree in respiratory therapy or related areas such as health sciences. The AARC 2009 Human Resources Study reported that $75 \%$ of RT faculty from accredited programs plan to retire by $2020 .^{7}$ Eight years ago, in a white paper, the AARC identified the need for RT graduate programs to prepare respiratory therapists for faculty positions in accredited programs. ${ }^{8}$ However, despite regional accrediting group requirements for baccalaureate allied health faculty to have a graduate degree in their specialty area, today there are only 4 master's degree and no doctorate programs with majors or concentrations in respiratory therapy. ${ }^{4,9}$ However, a recent 2009 survey of 52 baccalaureate-degree program directors (with a $100 \%$ response rate, and located throughout the United States, see Fig. 3), indicated that 22 will start a master's degree program for RTs by 2014. ${ }^{9}$ The AARC $2009 \mathrm{Hu}-$ man Resource Study surveyed 359 accredited RT programs and received responses from 242 directors $(67 \%){ }^{7}$ Forty-five programs awarded only the baccalaureate degree in respiratory therapy, and only 3 offered a graduate degree. However, 71 programs (29\%) indicated that students could earn a baccalaureate directly from their institution.

Student enrollment in 2009, in both associate-degree and the baccalaureate-degree programs, was quite limited, with a mean \pm SD graduating class of $18 \pm 13.7$ The baccalaureate-degree programs have a smaller average number of graduates than the associate-degree programs. The mean \pm SD number of baccalaureate-degree program graduates in 2009 was $15 \pm 9.9^{9}$ The present survey found that the mean \pm SD number of graduates will increase to $20 \pm 18$ by 2010 , and to $25 \pm 16$ by 2020 (see Table 10). ${ }^{4}$ If the total number of programs remains unchanged (435),
10,745 students will graduate from RT programs in 2020, compared to 8,656 that reportedly graduated in 2010 . More RT faculty with graduate degrees, teaching experience, and scholarly publication records are needed for both types of programs so they can expand and graduate more students who can successfully complete the RRT examinations and practice the competencies expected in 2015 and beyond. ${ }^{2,3}$ Funding and number of clinical affiliates, closely followed by faculty shortage, are reported to be the barriers to accepting more students (see Table 11). Twenty-one programs plan to offer a baccalaureate or master's degree in respiratory therapy in the future, 19 by 2015 .

A high proportion of the program directors favored requiring the RRT credential for RT licensure in 2015 and beyond. Further, they no longer see a rationale for the National Board for Respiratory Care to require graduates to take 3 examinations to earn the RRT credential. Many directors stated in the survey's comment sections that they believe that the CRT examination should no longer be offered. A majority of the voting participants at the third AARC 2015 and Beyond conference recommended that the AARC request that the National Board for Respiratory Care no longer offer the CRT examination after 2014, ${ }^{3}$ because:

- There are no differences in job duties between a RRT and a CRT credentialed therapist.

- RT programs prepare students for the RRT credential and it is time to require it for practice of the profession.

- Advancement in technology and assessment techniques requires a higher level of competency for entry into the profession.

- Having 2 credentials (CRT and RRT) confuses the public and healthcare workers as to what is necessary to practice as a respiratory therapist.

- Most institutions and communities do not differentiate between the CRT and the RRT credential.

- A 2-tiered credentialing process is time-consuming, expensive, and does not improve patient care.

- All the category of questions in the CRT examination can be incorporated in the RRT examination.

\section{Limitations}

This study is limited by the fact that RT program directors at 58 colleges (14\%) did not complete the survey. One of the more confounding and distressing aspects of the response to this survey was the large number of competency items the respondents intentionally left unselected (see Tables 1 through 9). For example, only 43 of the 54 baccalaureate-degree program directors selected the com- 
petency about teaching students how to critique the published literature (80\%), and only 122 of 294 of the associate-degree program directors selected this competency (41\%). The selection rate was even lower for the competency on teaching the meaning of general statistical tests (see Table 1). There was a similarly low selection rate on many of the competency area questions, and the selection rate was consistently lower among the associate-degree program directors than the baccalaureate-degree program directors. Since there was no possibility to respond to an individual item with "not currently taught in this program," the meaning of this selective lack of response is difficult to understand. Did the program directors simply overlook these items, or was the absence of a response an indication that the competency was not taught? Since the current requirements for accreditation of RT programs ${ }^{10}$ do not require the inclusion of specific content areas or specific numbers of hours of clinical instruction, we think it is likely that these non-responses actually are a statement that the competency is not taught by the program.

\section{Conclusions}

Our study provides important information from RT program directors regarding changes to the respiratory therapy education infrastructure that would assure competent respiratory therapists in the envisioned healthcare future and on their ability to ensure that their graduates have the competencies identified in the 2015 and Beyond conferences. Other major findings of this national survey are:

- Only one quarter of accredited RT programs that responded to this survey can directly award a baccalaureate degree in respiratory therapy or a health-science related area to their graduates.

- Two thirds of the respondent program directors favored requiring the RRT credential in 2015 and beyond.

- There was broad support for requiring that respiratory therapists obtain a baccalaureate or graduate degree after they have begun practice.

- Over one forth of the respondents favored requiring a baccalaureate-degree or graduate degree to qualify for a license to deliver respiratory care.

- Many respondents have concerns about finding necessary administrative and clinical resources to increase the number of graduates who will meet the needed competencies in 2015 and beyond, and adjusting or expanding curriculum to meet those competencies.

\section{REFERENCES}

1. Kacmarek RM, Durbin CG, Barnes TA, Kageler WV, Walton JR, O'Neil EH. Creating a vision for respiratory care in 2015 and beyond. Respir Care 2009;54(3):375-389.

2. Barnes TA, Gale DD, Kacmarek RM, Kageler WV. Competencies needed by graduate respiratory therapists in 2015 and beyond. Respir Care 2010;55(5):601-616.

3. Barnes TA, Kacmarek RM, Durbin CG. Transitioning the Respiratory Therapy Workforce for 2015 and Beyond. Respir Care 2011; 55(5):681-690.

4. Steering Committee of the Coalition for Baccalaureate and Graduate Respiratory Therapy Education. Roster of respiratory therapy programs awarding a baccalaureate or masters degree. http://www. cobgrte.org. Accessed October 20, 2011.

5. Hess DR. What is evidence-based medicine and why should I care? Respir Care 2004;49(7):730-741.

6. Stoller JK, Niewoehner DE, Fan VS. Disease management as an evolving role for respiratory therapists. Respir Care 2006;51(12): 1400-1402.

7. American Association for Respiratory Care. AARC 2009 respiratory therapist human resource study. Irving, Texas: AARC; June 2009.

8. American Association for Respiratory Care. Development of baccalaureate and graduate degrees in respiratory care: a white paper from the AARC Steering Committee of the Coalition For Baccalaureate and Graduate Respiratory Therapy Education. Irving, Texas: AARC; 2003. http://www.aarc.org/resources/bacc_edu/index.asp. Accessed October 11, 2011.

9. Barnes TA, Ward JJ. Survey and analysis of baccalaureate and graduate respiratory therapy education programs. Respir Care Educ Ann 2010;19:1-11.

10. Commission on Accreditation for Respiratory Care. New accreditation standards in effect as of June 1, 2010. Bedford, Texas: CoARC. http://www.coarc.com/29.html. Accessed October 11, 2011.

This article is approved for Continuing Respiratory Care Education credit. For information and to obtain your CRCE

(free to AARC members) visit

www.RCJournal.com

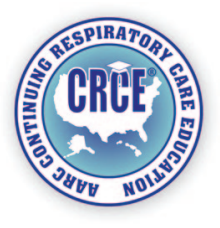

